\title{
Building a community of shared future for humankind -- an ethnological perspective
}

\author{
Liu Hong · Zhang Yuxuan
}

Received: 21 September 2018 /Accepted: 12 October 2018 / Published online: 06 November 2018 (C) The Author(s). 2018 Open Access This article is distributed under the terms of the Creative Commons Attribution 4.0 International License (http://creativecommons.org/licenses/by/4.0/), which permits unrestricted use, distribution, and reproduction in any medium, provided you give appropriate credit to the original author(s) and the source, provide a link to the Creative Commons license, and indicate if changes were made.

\begin{abstract}
Regional cooperation is one of the important symbols of world economic and political development. In fact, the benefits of cooperation among countries have been integrated as an important component of national interests. Many regional alliances have emerged on the heels of the European Union. The 2011 White Paper on China's Peaceful Development states that the international community should find new perspectives from the angle of the community of common destiny to seek shared interests and values of humankind. The recently released Report to the $19^{\text {th }}$ CPC (Communist Party of China) National Congress follows the Report to the 18th CPC National Congress is directing the conceptual development and theoretical framework for building a community of shared future for humankind. At present, a community of shared future for humankind has become a hot topic of world attention. Studies from different perspectives have emerged, including history, politics, economics, sociology, and geography. However, there is relatively scant research from the perspective of community evolution. What exactly does a community of shared future for humankind mean? What's new in this vision? Does it denote an end to nation-states? How do we understand the significance of this vision? This study tries to probe and answer these questions from an ethnological perspective to provide some reference for understanding the scientific significance of building a community of shared future for humankind.
\end{abstract}

\section{H. Liu}

Institute of Ethnology and Anthropology, Chinese Academy of Social Sciences, Bld.6, No.27,

Zhongguancun Nandajie, Haidian District, Beijing 100081, China

e-mail: liu.hong@cass.org.cn

\section{Y. Zhang $(\square)$}

School of Management, Mingzu University of China, No.27, Zhongguancun Nandajie, Haidian District, Beijing 100081, China

e-mail: xavierxzhang@live.com 
Keywords Community of shared future for humankind · Nation · Nationalities · Ethnic groups

\section{Introduction}

Human community: An interpretation from the ethnological perspective

In the Western political lexicon, community is made up of the Latin prefix "com" (meaning "together" and "with") and the Etruscan word "munis" (meaning "to have charge of"). Etymologically speaking, it comes from the ancient Greek word Koinonia which means communion and joint participation. For a long time, this term has been found in the literature as a supplement to the concept of society. It was first detached from the concept of society and separately used as a sociological concept by Ferdinand Tonnies (1855-1936). According to his theory, community could be defined as a type of social organization that shares common bonds around consanguinity, feelings or ethics. Thereafter, academia defined community as a social region, social association or group of people that follow generally accepted ethical standards in action and thought. In essence, this theoretical definition of community consists of "a group linked by specific factors".

From the ethnological perspective, a so-called human community is generally considered to share common historical, linguistic, geographical or cultural bonds and objectively distinguished from the "others". Examples include clans, tribes, tribal alliances, ancient empires, feudal kingdoms and feudal empires, as well as nations and nation-states that emerged in modern times.

It should be noted that the nationalist phenomenon originated in modern Europe, either as a social ideology or a socio-political movement; it is externally manifested in nation-states built on the basis of territorial politics. Thus, theorists of those times summarized this aspiration of "One People, One Nation, One State" as a concise formula later known as "classic nationalism" or "classical nationalism." Herein, nation refers to a community of shared political identity and economic interests, which is formed by people with common language and culture. Nation-state refers to a sovereign state of territorial unity and political independence established with the territorial space of such community as boundaries. The political ideology of this theory and scheme rests on the fact that contradictions and conflicts between national peoples derived from the imperial rule which has escalated into the most prominent problem in modern and contemporary times. The problem can be solved only by self-determination of national peoples to establish respective states to protect themselves. Unlike an empire with a power entity, a nation-state turns the social and political community that already exists in a state into the national community by identifying ethnicity at the national level or the so-called nation, in order to adapt to the binary relation between nation and state. The process of building a nation is completed when the nation recognizes the state, integrates its political demands into the national framework, and expresses its civic loyalty to the state. Therefore, "One People, One Nation, One State" has become the prevailing law and unchangeable tenet in building a nation-state. 


\section{Discussion}

Community of a shared future for humankind: A new expression of human community in the era of globalization

As an institutional structure created to resolve the conflicts between social forces and imperial regimes, nation-states have swept the world with the expansion of a capitalist world-system. This common form of state accepted internationally has impressive advantages and inherent weaknesses. It brings endless turmoil to the whole world along with economic prosperity to the capitalist one. Admittedly, the universal establishment of the nation-state system exerts a tremendous far-reaching impact in the history of human civilization. Relying on the capability of social mobilization, the nation-state as a form of national community greatly enhances national powers and functions while protecting national interests. Nevertheless, its inherent weakness has become visible. As a self-serving exclusive community, it emphasizes the supremacy of its own national interests. It mobilizes the human instinct of recognition to complete the internal integration, but this process deepens the suspicion and estrangement among states. Great powers continue to expand their international influence with capitalist development that facilitates increasing liberation of productive forces and gradual formation of a world market. In contrast, small nations or states have to choose their development path: either quickly transform themselves into nation-states to compete in the capitalist world or be eliminated or reduced to the colonies of capitalist nation-states. In this way, nation-state becomes the basic political unit and legal unit of countries in the world-system. At the same time, an international pattern full of power, conflicts, competition and exploitation takes shape as an inevitable result under the world-system of nation-states.

The era of globalization calls for a new type of human community. With the advancement of globalization, political multi-polarization, economic globalization, and social information, there is a movement towards rapid and closer links among countries. Human society has entered an era of sharing both risks and benefits. Global issues, either traditional or non-traditional, arise from local conflicts, ethnic separatism, racism and terrorism which are hardly addressed in the nation-state system. Any issue specific to country or region can draw worldwide attention and may evolve into a global concern. A country cannot single-handedly gain an absolute sense of security or long-term benefits in a turbulent world.

A community of shared future for humankind has drawn growing attention from domestic and international communities in recent years. It transcends the cornerstone of identity for pre-existing human communities, and replaces language, geography, history and blood relationship with a shared future as the bonds that closely link the rights and responsibilities of its members. The shared future is a trend of development that combines universal manifestations with particular interests. A community of shared future for humankind abandons the traditional international relations featuring power, conflicts, competition and exploitation, and surpasses the institutional mechanisms of original nation-states. It advocates the liberation of nation-states from the traditional international relations to renew the world order for common development in the spirit of seeking a common ground while 
respecting differences. As a consequence, such a community regards win-win cooperation as a universal expression towards the future development trend of human society.

Essence of a community of shared future for humankind: Sublation of the nationstate system

In the aftermath of World War II, people, especially Europeans from the nation-states that were involved in war, began to reflect upon their ideologies and improved their practices regarding the nation-state system on which they once prided themselves. Regional groupings sprang up, including the European Coal and Steel Community, European Communities, European Union (EU), and Association of Southeast Asian Nations (ASEAN). With the advent of the globalization era, unsatisfactory performances became more visible such as limited governance capacity and uncertain future development. Increasing attention has been directed towards nation-state governance strategies and the theoretical knowledge, assumptions and practical exploration about the future of nation-states.

A community of shared future for humankind, which is new in the era of globalization, sublates the existing system of nation-states.

First, building a community of shared future for humankind will strengthen rather than put an end to the nation-state system. The purpose is to inject new vitality to nation-states with a view towards common development of humankind. It offers a realistic approach to self-protection for people of all countries around the world. Facing the outbreak of world wars and frequent incidents related to terrorism, ethnic strife, ethnic separatism and populist nationalism, the majority have realized that the limited scope of the nation-state system, national self-interest and unilateral sovereign recognition usually lead to mutual strife and self-destruction. Adjacent countries that over-pursue national security virtually form a joint force to create an insecure atmosphere within a broader scope. Only by linking sovereignty and restricting instinctual demands can the fundamental goal of national sovereignty be effectively achieved and the space for safe survival and development be obtained. Under the framework of building a community with shared future for humankind, nation-states have been integrated into the regional economy or a broader world. The common national economic activities maintain close relations of cooperation, in which sovereignty acts a role.

As to the starting point of building a community of shared future for humankind, the Report to the 19th CPC National Congress made it clear that "the future of the world rests in the hands of the people of all countries," and "the people of all countries" build a community of shared future for humankind to create a bright tomorrow for all of us. It is apparent that in today's world-system, such a community further demonstrates and protects national interests without the premise of terminating the nation-state system. Herein, "countries" refer to members of the existing world-system of sovereign states.

Secondly, a community of shared future for humankind will be built on the basis of equity, overcoming the intrinsic irrationality in the establishment of traditional nation-states advocated by classical nationalist theorists. The vision highlights "cooperation" in the governance of sovereign states, and advocates "accommodating others' interests while pursuing one's own." A community of this 
kind favors "more equal and balanced partnerships for global development, featuring joint efforts and shared rights and responsibilities." Its aim is to reduce or even eliminate barriers and conflicts among countries.

The irrationality of nation-states becomes more visceral when examining the issue of development as part of the establishment of the Westphalian system in the seventeenth century. More specifically, nation-states are established on the basis of political movements and mutual compromises of relatively strong peoples, with little or no considerations are given to relatively weak or marginalized peoples. For the purpose of providing theoretical support for such political movements and to prove its rationality and legitimacy, the dominant social interest groups proposed at that time the aforementioned formula that seemingly applies to all of the peoples. In fact, the long-term practice of the vision of "One People, One Nation, One State" has brought unimaginable significant negative consequences. Some "stateless nations" are unwilling to accept the "multinational states" reality and the statepattern of the world. This plants the theoretical roots for endless complex ideological and ethnic conflicts and separatist practices in some countries and regions.

Thirdly, building a community of shared future for humankind serves the purpose of a win-win situation for the peoples of all countries because it leads to an abandonment of the traditional mindset of nation-states regarding the supremacy of their own interests. It "promotes the common development of all countries while striving for one's own development" and "enhances the common interests of mankind". While the classical nationalism is detached from the reality, this vision puts "win-win" into the objective reality of peaceful coexistence and common development, and overcomes the unrealism of classical nationalism.

Practice has proved that its feature of unrealism is exposed when the classical nationalist discourse or vision is put into practice. Among thousands of groups of "people" in the world, only less than two hundred have been qualified as "nation" and able to establish independent states since the French Revolution in 1789. The rest exist as "sub-nations" (usually referred to as nationalities), "peoples across the boundary" or "ethnic groups". The loyalty of citizens required by nation-states is overwhelmed by the legitimacy and rationality of international immigrants. The external functions of nation-states and the relations among nation-states do not follow exactly the design and plan of classical nationalist theorists. There is scant evidence that neighboring countries are free from conflicts and wars.

\section{Conclusion}

Community of shared future for humankind: Future development direction of human community

The nation-state system is based on a rheological national identity. To ensure the stability of national identity, nation-states need to adopt a series of full-fledged institutionalized mechanisms. Among them, Western European nation-states established an institutional framework based on a capitalist constitutional system. It is frustrating that the mechanisms used to strengthen integration within the international community also 
place these nation-states in a long-term state of (potential) war. On the one hand, original nation-states believe that there is an intrinsic opposition among them or a zero-sum game featuring strife and exploitation. Only the long-term dominance in international competition can secure their continuation and development. Competition becomes the institutional reliance for the original nation-states, and the triumph over opponents turns out to be the sole purpose of the state and the only way to achieve state security. On the other hand, when external enemies disappear, original nation-states will be weakened in multiple dimensions. In the dimension of vision, the reality of multinational society runs counter to the founding creed of "One People, One Nation, One State". In the cultural dimension, religious pluralism, especially the spread of Islam, has disintegrated the unity of traditional Christian culture. In the institutional framework, the power of the central government has been divided again and again, while that of local governments has continuously strengthened. As a result, the identity of the national community is differentiated. This leads to the internal collapse of loyalty of citizens and the subsequent crisis of national separatism manifested in independent referendums. In this sense, the institutionalized mechanisms lead nation-states in a struggle or opposition against other countries or it create swirls of regional unrest caused by national separatism, exclusionism and terrorism.

Classical theorists of nationalism envisaged that the establishment of nation-states would avoid intense violent conflicts between nations, but this ideal has not materialized. On the contrary, it is precisely in the era of nation-states that human warfare scaled up unprecedentedly. In the aftermath of World War II, the ethnic conflicts at the international level were curbed to a certain degree through the Cold War. However, inter-ethnic conflicts within multinational countries were very common and led to the disintegration of certain countries and ethnic massacres. A variety of organizations and forces of peaceful and violent national separatism have turned out to be a potential social and political issue in many countries.

After the World War II, the imperialist colonial system was disintegrated. A large number of colonial countries in Asia, Africa and Latin America gained independence and established their own nation-states one after another. However, the establishment occurred more frequently under the pressure of the nation-state world-system or with the "help" of original Western nation-states. These emerging nation-states copied the practices from original Western nation-states to a considerable degree in both integrating national communities and building institutional mechanisms, referred to as "copinism". The majority are multinational countries that have neither the tradition of Christian ethics nor an agreeable system of jurisprudence and philosophical governance. As a result, the institutional flaws were also introduced from original nation-states and revealed in the form of more intense violence or conflicts.

The formation and development of regional alliances, such as the EU and ASEAN, show that states are not the only arena of inter-ethnic politics. Sovereign political units and inter-ethnic political entities are diversified. There is considerable international space to further unite nation-states. Their successes and difficulties encountered tell people from different perspectives that the nation-state as a form of existence must give way to national interests when conflicting with the latter. The pursuit of nation-state interests as supreme values cannot really safeguard the survival and development of the nation. 
The vision of a community of shared future for humankind, once put forth, has been widely recognized in the world. It is an "outlook on world-system construction" beyond nation-states and ideology in conformity with the needs of development in the era of globalization. The CPC and State leaders have expounded on this vision in more than one hundred important international and domestic occasions, including the connotations, pathways and roadmaps for achievement. The vision was written for the first time into the United Nations resolutions in February 2017 and into the resolutions of the UN Security Council and the UN Human Rights Council in March 2017. At the recently concluded 19th CPC National Congress, the CPC Central Committee once again pointed out the direction towards the conceptual development and theoretical construction. The report noted that "The world is undergoing major developments, transformation, and adjustment, but peace and development remain the call of our day...And yet, as a world we face growing uncertainties and destabilizing factors... The future of humankind hinges on the choices people of all countries make. We, the Chinese, are ready to work with the people of all other countries to build a community with shared future for humankind and create a bright tomorrow for all of us." It not only charts the overall layout and realistic pathway, but also gives more realistic and up-to-date meaning of building a community of shared future for humankind.

"Delicious soup is made by combining different ingredients." The diversity of human civilizations not only defines our world, but also drives progress of humankind. Since the inception of the Westphalian system, nation-states have reshaped the overall pattern of the world as the only political organizational structure recognized internationally. Due to differences in spatial and temporal cycles in advancing the nation-state process, countries adopted different approaches to address varying problems.. The nation-state is not a closed system and mechanism. There is not yet a perfectly accurate path for practice in this regard. While Western civilization provides reference for the nation-state theory, Chinese civilization has also been solidified in Chinese cultural genes, laying the foundation for renewing the interpretation on nation-state in the category of community. "Peace and harmony should prevail." "The world will be built into a harmonious whole." These people-oriented thoughts respected by Chinese people for long reflect the expectation of and outlook on a community of shared future for humankind. They have been demonstrated in the building of the Chinese nation. Currently, the system of original nation-states shows institutional flaws, and the human society's problems are reflected in these weaknesses. In this context, the vision of a community of shared future for humankind depicts a huge picture of win-win cooperation for the future development of human society. As the scroll expands slowly, China will surely contribute more Chinese wisdom and style to building a community of shared future for humankind.

Building a community of shared future for humankind is a new concept and initiative proposed to seek common development of the whole world. It demonstrates the determination and capability of the growing Chinese nation to build an open and inclusive inter-ethnic order and world system that features lasting peace, universal security, and common prosperity. By historically surpassing and sublating the theory and practice of classical nationalism, the vision of vital significance will exert profound impact on the contemporary world beyond conventional estimations. 
Humans live together on the planet and must safeguard the shared homeland. A community of shared future for humankind is not an imaginary spiritual home, but a world in which people of all countries eagerly seek recovery from common risks and reshape mutual trust and interdependence. This scientific concept of constructing an up-to-date world-system will lead to the future direction of nation-states. People of all ethnic groups in the world will work together to make true the dream of "Our Planet and Our Homeland".

Acknowledgements Not applicable.

\section{Funding}

Not applicable.

\section{Availability of data and materials}

Data sharing not applicable to this article as no datasets were generated or analyzed during the current study.

\section{Authors' contributions}

$\mathrm{HL}$ is responsible for the overall writing of the article; $\mathrm{YZ}$ is responsible for the framework design of the article and data collection. Both authors read and approved the final manuscript.

\section{Ethics approval and consent to participate}

Not applicable.

\section{Consent for publication}

Not applicable.

\section{Competing interests}

The authors declare that they have no competing interests.

\section{Publisher's Note}

Springer Nature remains neutral with regard to jurisdictional claims in published maps and institutional affiliations. 